\title{
Deneysel Diyabette Deri Hasarına Karşı Propolisin İyileştirici Etkilerinin Araştırılması
}

\section{Investigation of The Ameliorative Effects of Propolis Against Skin Damage in Experimental Diabetes}

\author{
Sibel TÜREDi ${ }^{1}$ \\ ${ }^{1}$ Harran Üniversitesi, Tıp Fakültesi Histoloji ve Embriyoloji Anabilim Dalı, Şanlıurfa, TÜRKiYE
}

Öz.

Amaç: Bu çalışmada deneysel Diabetes Mellitus'un dermal doku üzerinde oluşturduğu hasara karşı propolisin muhtemel olumlu etkilerini histopatolojik parametreler ile araştırmaktır.

Materyal ve Metod: Çalışmamızda 24 adet 10-12 haftalık Wistar Albino türü erkek sıçanlar Kontrol, Propolis $100 \mathrm{mg}$, DM ve DM+Propolis (100mg) olarak rastgele 4 gruba ayrıldı. $0.1 \mathrm{Molar}(\mathrm{Ph}: 4,5)$ sitrat tamponunda çözülen tek doz $60 \mathrm{mg} / \mathrm{kg}$ Streptozotosin (inroperitoneal) ile deneysel diyabet oluşturuldu. Deney süresinin bitiminde (28. Gün) tüm gruplar sakrifiye edildi ve elde edilen dermal dokularda Hematoksilen\&Eozin ve Masson Trikrom boyamaları ile histopatolojik değerlendirme yapıldı.

Bulgular: Yapılan histopatolojik değerlendirmede; kontrol ve Propolis 100mg gruplarına ait deri örneklerinin normal morfolojik yapıda olduğu izlendi. DM grubunda çok tabakalı epitelde incelme, dejenerasyon, dermis tabakasında yer alan bağ dokusunda ayrılma ve azalma gözlenirken DM+Propolis $100 \mathrm{mg}$ grubunda ise bu bulgularda belirgin şekilde bir iyileşme izlendi.

Sonuç: Bu çalışma, Propolis 100mg dozunun biyolojik özelliklerin diyabetin dermal dokuda meydana getirdiği cilt hasarını morfolojik düzeyde önleyebileceğini göstermiştir.

Anahtar Kelimeler: Deri, Diabetes Mellitus, Propolis, Histopatoloji, Rat

Abstract

Background: The purpose of this study was to investigate the possible positive effects of propolis against the damage caused by experimental Diabetes Mellitus on the dermal tissue with histopathological parameters.

Materials and Methods: Twenty-four male Wistar Albino rats aged 10-12 weeks were randomly assigned into four groups as; Control, Propolis $100 \mathrm{mg}$, DM and DM+Propolis (100mg). Experimental diabetes was induced with a single dose of $60 \mathrm{mg} / \mathrm{kg}$ streptozotocin (intraperitoneally) dissolved in 0.1 Molar (Ph: 4.5) citrate buffer. At the end of the experiment period (Day 28), all groups were sacrificed and histopathological evaluation was performed on the dermal tissues by Hematoxylin\&Eosin and Masson Trichrome stainings.

Results: In histopathological evaluation; normal morphological structure were observed in the skin samples of the control and Propolis $100 \mathrm{mg}$ groups. Thinning of the multilayered epithelium, degeneration, separation and decrease in the connective tissue in the dermis layer was observed in DM group, but these findings were significantly improved in the DM+Propolis $100 \mathrm{mg}$ group.

Conclusions: The present study showed that the biological properties of Propolis $100 \mathrm{mg}$ dose may prevent skin damage caused by diabetes at the morphological level in dermal tissue.

Key words: Skin, Diabetes Mellitus, Propolis, Histopathology, Rat
Sorumlu Yazar / Corresponding Author

Dr.Öğr. Üyesi Sibel TÜREDi

Harran Üniversitesi, Tıp Fakültesi Histoloji ve Embriyoloji Anabilim Dalı, 63000, Şanlıurfa, TÜRKIYE

e-mail:

sibelturedi3361@hotmail.com; sibelturedi@harran.edu.tr

Geliş tarihi / Received: 13.08.2021

Kabul tarihi / Accepted: 19.08.2021

DOI: $10.35440 /$ hutfd.982441 


\section{Giriş}

Diabetes Mellitus (DM) pankreasın Langerhans adacıklarındaki beta hücrelerinin tahribatı sonucu insülinin eksikliği ve buna bağlı kan şekeri yüksekliği (hiperglisemi) ile karakterize olan, glikoz, protein ve lipid metabolizmalarını bozarak karakteristik komplikasyonlara neden olan metabolik bir hastalıktır (1). Diyabette kronik hipergliseminin oksidatif strese neden olduğu ve serbest radikallerdeki artışın diyabetin kronik komplikasyonlarında önemli bir rol oynadığına inanılmaktadır. Reaktif oksijen türlerinin (ROS) oluşumu, özellikle kalp, böbrek, göz, sinir, karaciğer ve gastrointestinal sistemde oksidatif hasara yol açar. DM'nin neden olduğu metabolik rahatsızlıklardan diğer organlar gibi deri de etkilenir. Deri vücudun en büyük organıdır, tüm vücut yüzeyini kaplar ve çevre koşullarının zararlı etkilerine karşı korur. DM'nin klinik seyrindeki deri komplikasyonları çok ciddi bir sağlık problemi olmakla birlikte etiyolojileri henüz tam olarak açıklanmamıştır (2). Kolayca gözden kaçan, genellikle diyabetle ilişkilendirilen kutanöz komplikasyonlar arasında kaşıntı, mantar ve bakteriyel enfeksiyonlar, ülserler yer alır ve bu durum hastaların yaşam kalitesi olumsuz yönde etkilemektedir. Bu semptomlar, diyabet uyarısı olarak hizmet eder ve diyabetin mikro vasküler komplikasyonlarını gösterir. Bu nedenle, diyabetik hastalarda cilt değişikliklerinin acil olarak tanımlanması uygun diyabet bakımı için çok önemlidir (3). Propolis bal arıları tarafından ağaçların kozalak ve kabuklarında, bitkilerin tomurcuk ve filizlerinden toplanan çeşitli yağlar, polenler, özel reçine ve mumsu maddelerin karışımından oluşan bir arı ürünüdür (4). Yapılan çalışmalarda propolisteki flavonoidler ve bunlarla ilgili bileşiklerin serbest radikal temizleme etkisi en fazla olan bileşikler olduğu gösterilmiştir (5). Bununla birlikte antiviral, antiinflamatuar, antineoplastik, antibakterial, immun düzenleyici ve hepatoprotektif etkilerinin olduğu pek çok çalışmada ifade edilmiştir (6-10). Tip 2 Diabetes Mellitus için alternatif bir şifa terapisi olarak propolis kullanımının DM hastalığını hafiflettiği iddia edilmektedir (11).

Bu çalışmanın amacı; streptozotosin (STZ) ile indüklenen sıçan diyabet modelinde, DM'nin dermal dokuda meydana getirdiği histopatolojik değişiklikleri değerlendirmek ve propolisin muhtemel deri hasarı üzerine koruyucu etkilerini araştırmaktır

\section{Materyal ve Metod}

Etik Prosedür, Deney Grupları ve Histolojik Preparasyon Bu çalışmada Wistar Albino cinsi 24 adet (12-16 haftalık, 330-400 g ağırlık) erkek sıçanlar kullanıldı. Hayvanlar Harran Üniversitesi, Deney Hayvanları Ünitesi'nden (Şanlıurfa, Türkiye) temin edildi. Çalışmaya Hayvan Deneyleri Yerel Etik Kurulu'nun (Karar no: 2021/005/07) onayı alınarak başlandı. Bütün hayvanlar oda sıcaklığı $22 \pm 2$ C, nem $(50 \% \pm 10)$ ve 12 saat karanlık / 12 saat aydınlık kontrollü standart laboratuvar ortamında muhafaza edildi. Deney süresi boyunca standart laboratuvar hayvan yemi ve ad libitum su verildi. Sıçanlar aşağıda belirtildiği gibi 4 gruba ayrıldı:

Kontrol grup (n:6): Tek doz 0.1 Molar (Ph: 4,5) sitrat tamponu (i.p.) akabinde deney süresinin sonunda sakrifiye edildi.

Propolis grubu (n:6): Deney süresi boyunca (28 gün) propolis $100 \mathrm{mg} / \mathrm{kg} /$ gün oral yol ile uygulandı (12).

DM grubu (n:6): 0.1 Molar (Ph: 4,5) sitrat tamponunda çözülen tek doz $60 \mathrm{mg} / \mathrm{kg}$ STZ i.p olarak uygulandı; 72 saat sonra sıçanların kan şekeri bakıldı ve kan şekeri 300 mg / dl üstü DM kabul edildi (13).

DM + Propolis grubu (n:6): $60 \mathrm{mg} / \mathrm{kg} \mathrm{STZ} \mathrm{ile} \mathrm{DM} \mathrm{oluşturu-}$ lan sıçanlara deney süresi boyunca (28 gün) propolis 100 $\mathrm{mg} / \mathrm{kg} /$ gün oral yol ile verildi.

Deney süresinin bitiminde tüm sıçanlar derin anestezi altında (Ketamin 90 mg/kg+Ksilazin 10 mg/kg) (Ketalar ${ }^{\circledR}$, Eczacıbaşı Co., Istanbul, Turkey; Rompun \%2, Bayer Healthcare LLC. Kansas, ABD) kansızlaştırma yöntemi ile sakrifiye edildikten sonra deri dokuları \%10 formol solüsyonu içerisinde tespit edildi ve ardından rutin histolojik doku takip işlemine alınıp parafine gömülerek bloklandı. Rutin histolojik doku takip prosedürü sonrası elde edilen parafin bloklardan yarı otomatik mikrotom (Thermo Shandon Finesse ME+ Microtome, Runcorn, UK) ile5 $\mu \mathrm{m}$ kesitler alındı, hematoksilen \& eozin (H\&E) ve Masson Trikrom (Trichrome Masson Stain Kit-Sigma Aldrich, Code: HT15$1 \mathrm{KT}$, St. Louis, USA) ile boyanarak ışık mikroskobunda histopatolojik değerlendirmesi yapıldı ve tüm preparatlar Zeiss Axioskop II (Carl Zeiss Microscopy GmbH, Göttingen, Almanya) marka mikroskop kullanılarak ayn mikroskoba monte edilmiş Zeiss Axiocam MRc kamera modeli ataçman (Carl Zeiss Microlmaging GmbH, Göttingen, Almanya) ile fotoğraflanıp bilgisayara kaydedildi.

\section{Bulgular}

Kontrol, Propolis $100 \mathrm{mg}$, DM ve DM+Propolis $100 \mathrm{mg}$ gruplarında histopatolojik değerlendirmelere ait morfolojik görüntüler sırasıyla Resim 1, Resim 2, Resim 3, Resim 4'te gösterilmiştir. Kesitlerin morfolojik değerlendirmesine göre; kontrol ve propolis $100 \mathrm{mg}$ gruplarına ait deri dokusu preparatlarında; epidermiste çok katlı yassı keratinize epitel tabakasının bütünlüğünü koruduğu, epidermis, dermis ve hipodermis sınırlarının normal morfolojik özellikleri gösterdiği ve dermis tabakasınında bağ doku, kollajen yoğunluğunun yeterli olduğu izlendi (Resim 1A-D; Resim 3A-D). DM grubunda deri dokusunun çok katmanlı epitel tabakasının belirgin şekilde inceldiği, epitel tabakasında bozulmalar ve dejenerasyon (Resim 2A, B), epitel altı bağ doku değerlendirmesinde; papillar dermişin gevşek bağ dokusunun kaybolduğu, retiküler dermişte ise kollajen miktarının belirgin şekilde azaldığı gözlendi (Re$\operatorname{sim} 4 \mathrm{~A}, \mathrm{~B})$. Bununla birlikte DM+Propolis $100 \mathrm{mg}$ grubunda epitel tabakasında görülen bozulmaların düzeldiği, epitel katmanlarında artış görülmeye başlandığı, papillar ve retiküler dermiste DM grubuna göre kollajen miktarında artış olduğu gözlendi (Resim 2C, D; Resim 4C, D). 


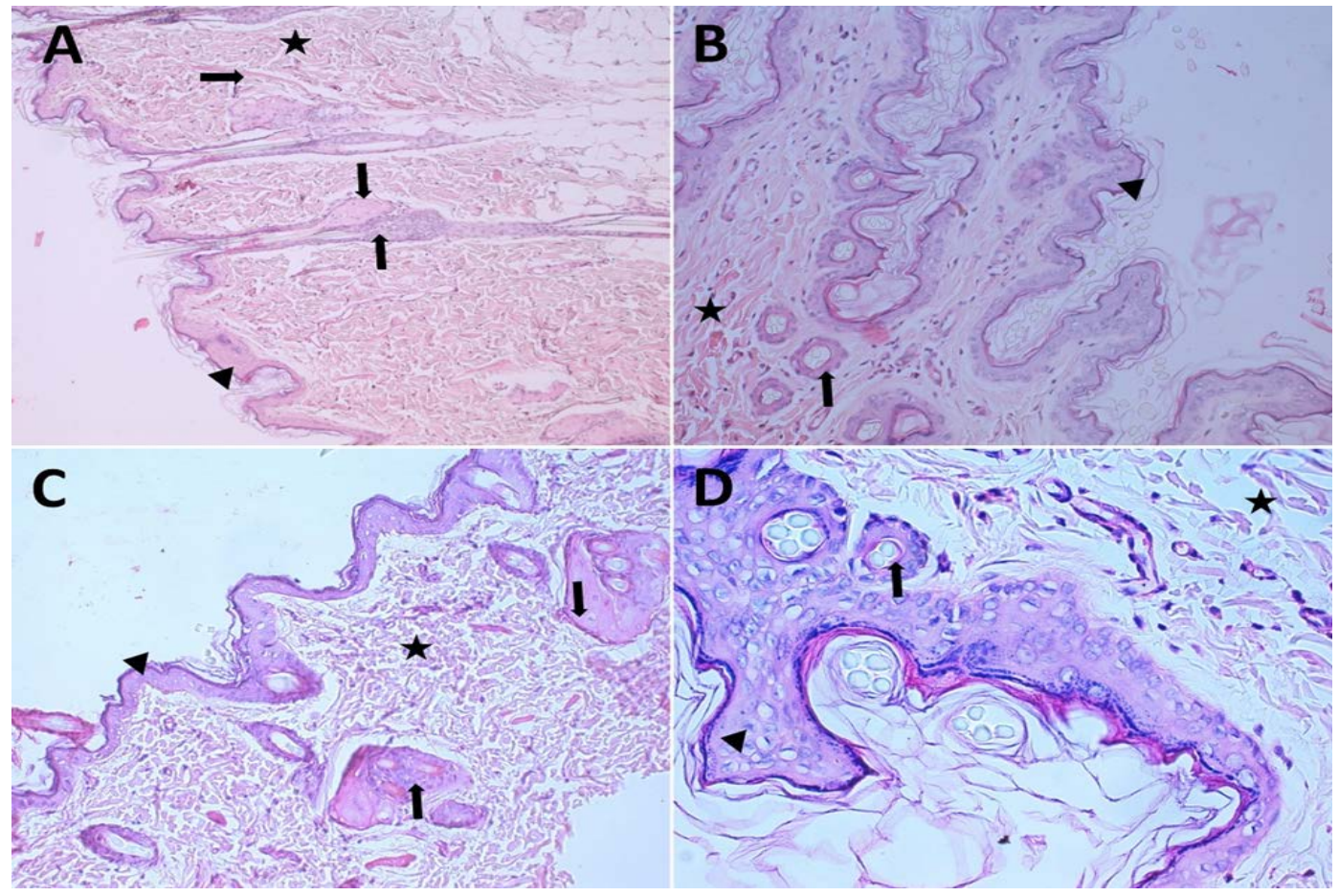

Resim 1: Deney Gruplarına Ait Dermal Dokunun Işık Mikroskobik Mikrografları.

Kontrol Grubu (A, B), Propolis 100 mg Grubu (C, D). Çok katlı yassı keratinize epitel (ok başı), erektör pili kası (sağ ok), sebase bez (aşağı ok), kıl folikülü (yukarı ok), dermis tabakası (yıldız). (H\&E, 20X, X40).

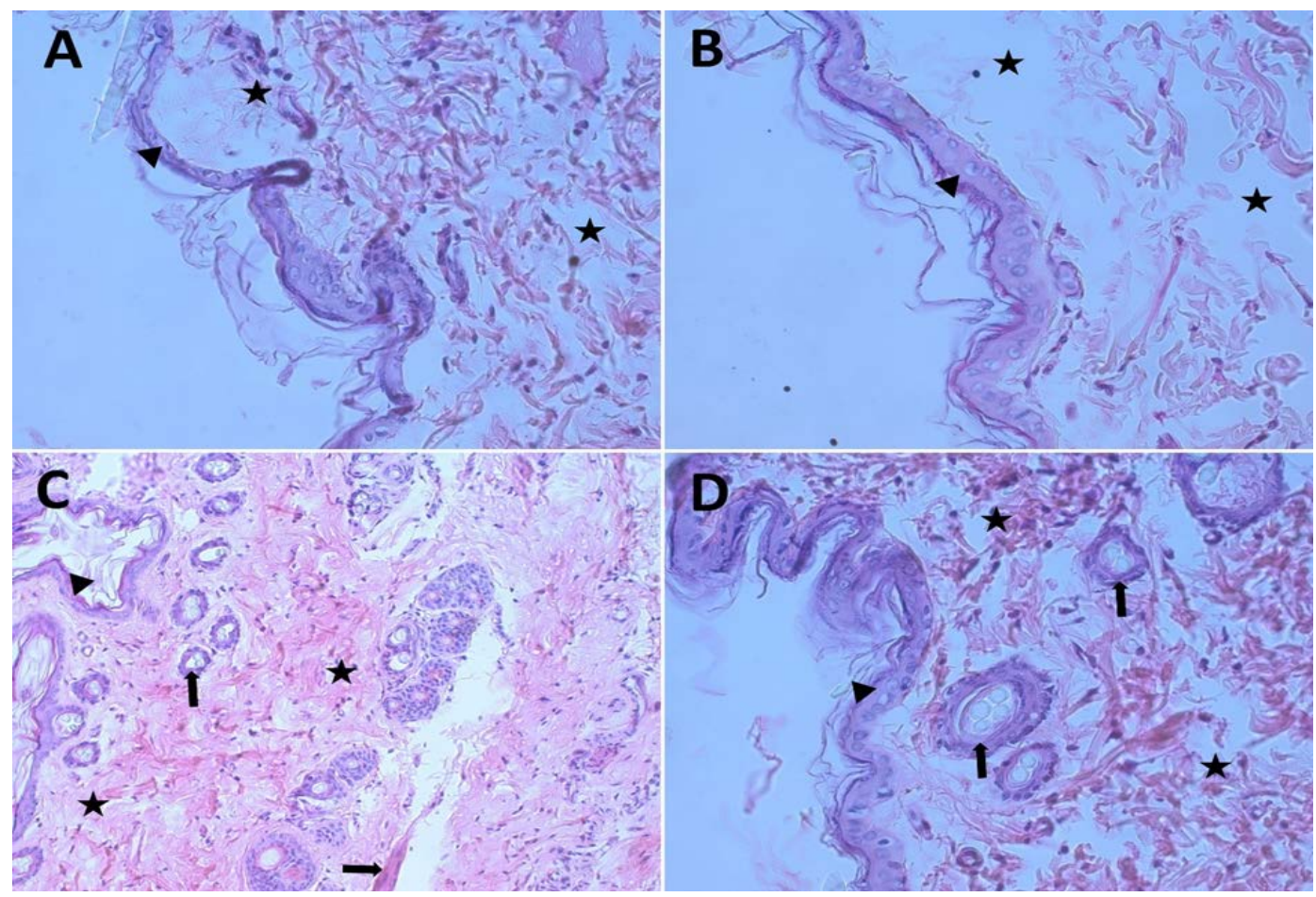

Resim 2: Deney Gruplarına Ait Dermal Dokunun Işık Mikroskobik Mikrografları.

DM Grubu (A, B), DM+Propolis 100 mg Grubu (C, D). Çok katlı yassı keratinize epitel (ok başı), erektör pili kası (sağ ok), kıl folikülü (yukarı ok), dermis tabakası (yıldız). (H\&E, 20X, X40). 


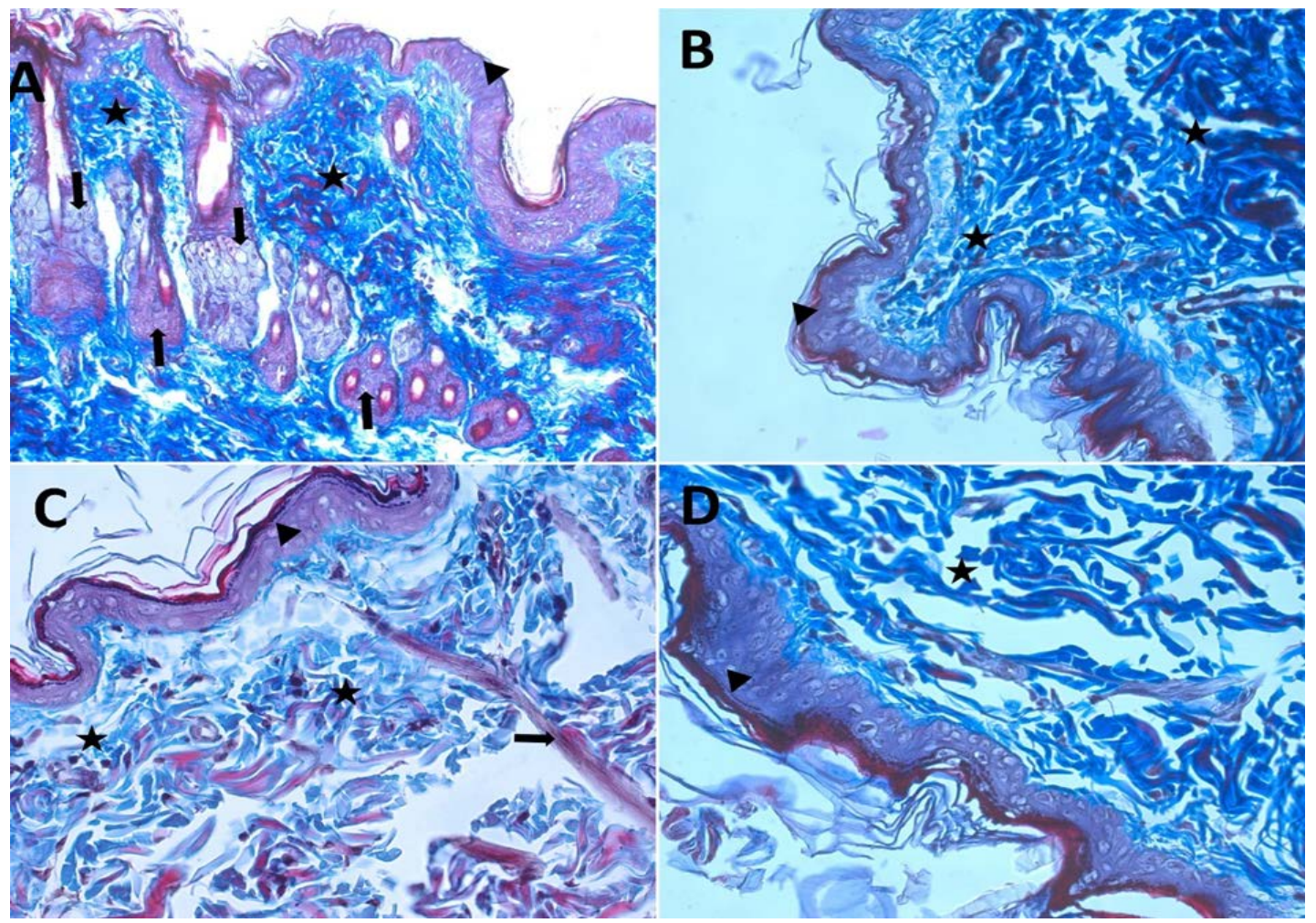

Resim 3: Deney Gruplarına Ait Dermal Dokunun Işık Mikroskobik Mikrografları.

Kontrol Grubu (A, B), Propolis 100 mg Grubu (C, D). Çok katı yassı keratinize epitel (ok başı), erektör pili kası (sağ ok), sebase bez (aşağı ok), kıl folikülü (yukarı ok), dermis tabakası (yıldız). (Masson Trikrom, 20X, X40).

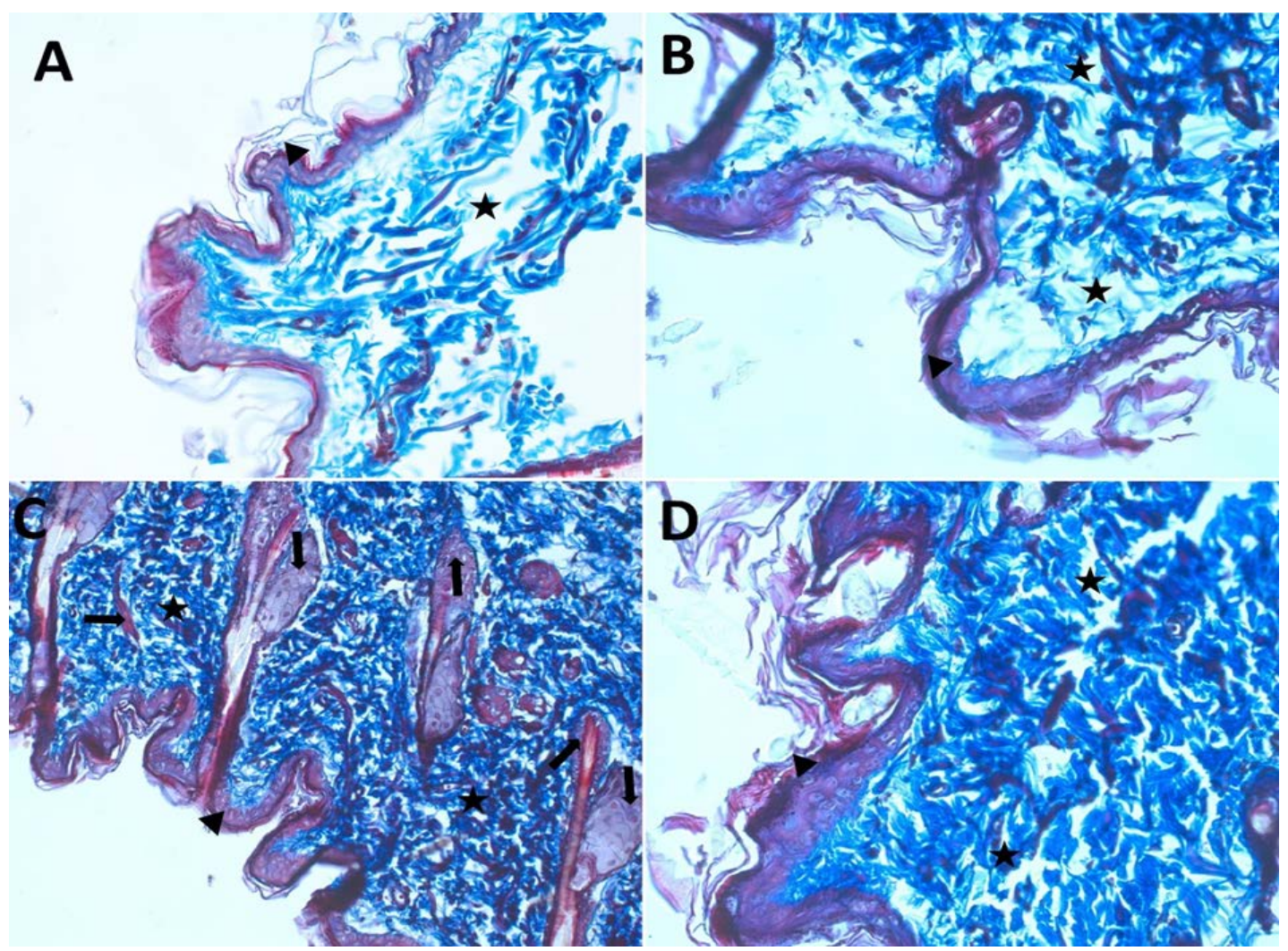

Resim 4: Deney Gruplarına Ait Dermal Dokunun Işık Mikroskobik Mikrografları.

DM Grubu (A, B), DM+Propolis 100 mg Grubu (C, D). Çok katlı yassı keratinize epitel (ok başı), erektör pili kası (sağ ok), kıl folikülü (yukarı ok), dermis tabakası (yıldız). (Masson Trikrom, 20X, X40). 


\section{Tartışma}

Diabetes mellitus, kardiyovasküler, gastrointestinal, retinal, periferik sinir, böbrek ve karaciğer fonksiyon bozuklukları açısından ciddi bir risk faktörü olan yaygın bir metabolik hastalıktır (2). Bununla birlikte diyabetik hastaların $\% 75$ 'inden fazlasında cilt problemleri de gözlenmekte ve bu durum diyabet hastalarının yaşam kalitesini belirgin derecede düşürmektededir (14). DM önemli bir sağılk problemidir ve indüklenen dermal hasarı en aza indirgemek için klinisyenler tedavi sürecinde çok büyük bir mücadeleler vermektedir.

Bu çalışmada STZ kaynaklı DM modeli oluşturularak, 28 günlük dönem açısından dermal dokuda morfolojik inceleme yapılmıştır. Elde edilen bulgulara göre; kontrol ve propolis $100 \mathrm{mg}$ gruplarına ait deri dokusunun tüm tabakalarının bütünlüğünü koruduğu ve normal morfolojik özellik gösterdiği fakat DM grubuna ait deri örnekleri incelendiğinde ise epidermiste çok katmanlı epitel tabakasının belirgin şekilde inceldiği, epitel hücrelerinde dejenerasyon izlenmiştir. Deri dokusu ve hücreleri, normal metabolizmayı ve yapısal bütünlüğü korumak için sabit bir çoğalma hızına sahiptir. Epidermal dokuda, bazal epidermal hücreler sürekli çoğalıp, farklılaşır epitele doğru hareket eder ve sonunda cilt yüzeyinden dökülür $(15,16)$. Bu durum sağlıklı bir cilt yapısının fonksiyonlarını sürdürebilmesi için gerekli olan normal bir süreçtir. Fakat diyabetli hastalarda deride incelme çok yaygın olarak gözlenen bir klinik bulgudur $(15,17)$. Chen ve ark.'nın (2010) DM'nin deri dokusunda patolojik ve fizyolojik değişikliklerinin incelendiği deneysel bir çalışmada; diyabetik sıçanların cilt dokularında, cilt glikozunda bir artışa ek olarak, çok katlı yassı epitel tabaka yapısında kayıp, cilt kalınlığında azalma gibi cilt yapısında önemli yapısal bozukluklara neden olduğu gözlenmiştir (15). Bu genel ve histolojik gözlemler, DM cildinde epidermal hücre proliferasyonunun bir işlev bozukluğunun olabileceğini düşündürmektedir. Ayrıca lokal dokudaki artan glikozun, glikoz metabolizmasında lokalize bir bozulmaya başlamadan önce biyolojik süreçte birtakım histolojik değişikliklerin varlığı ile ciltte böyle bir "endojen hasar", olabileceğini göstermektedir. Sonuç olarak, diyabetik hastaların deri dokusunda hasar oluşmadan bütünlüğünü ve devamlılığını etkilemeden meydana gelir ve derideki yüksek glikoz seviyelerinin, toksik maddelerin birikiminin aracılık ettiği dermal hücrelerin veya matrisin işlev bozukluğundan kaynaklanır. Bu durum vasküler nöropatinin neden olduğu cilt nekrozundan farklı bir durum olmakla birlikte, aynı zamanda yaralanmaya karşı DM'li derinin sağlıklı normal deriden farklı bir duyarlılığa sahip olduğunu da göstermektedir (15).

Bu çalışmada DM grubu deri örneklerinde epitel altı bağ doku değerlendirmesinde; papillar dermisin gevşek bağ dokusunun kaybolduğu, retiküler dermiste ise kollajen miktarının belirgin şekilde azaldığı görülmüştür. Atrofi ve kollajen azalması, diyabetik cildin belirgin özellikleri olarak kabul edilir. Yapılan hayvan deneyleri, diyabetik ciltte kollajen katabolizmasının arttığını göstermiştir (18). Suh ve ark.'nın (2018) yapmış olduğu bir çalışmada STZ ile indüklenen diyabetik sıçanların deri dokusunda ortalama kollajen miktarının azaldığını diyabetik derideki kollajendeki kalitatif değişiklikleri doğruladığını belirtmişlerdir. Ayrıca atomik kuvvet mikroskobu analizi sonucuna göre kollajen fibrillerin diyabetik deride diyabetik olmayan deriye göre\% 76 daha pürüzlü olduğunu göstermiştir (2). Argyropoulos ve ark.'larının (2016) diyabetik sıçanlarda derideki ortalama kollajen miktarının diyabet indüksiyonundan 14 hafta sonra yaklaşık \%46 azaldığını göstermiştir (19). Chen ve ark.'nın (2010) yaptığı çalışmada DM grubunda, dermiste kollajen yapısında dejenerasyon, lif yapısında atrofi, mikrovasküler bazal membranda kalınlaşma gözlenmiştir. Bu sonuçlarla tutarlı olarak, bulgularımız STZ ile indüklenen DM modelinin sıçanlarda ortalama cilt kollajen miktarının yaklaşık olarak azaldığını doğrulamaktadır. Diyabetin dermal tabakanın incelmesine neden olmakla birlikte derideki sinir ekspresyonundaki azalma ile paralel bir şekilde seyrettiği belirtilmektedir (15). Hücre dışı matrisin başlıca yapısal proteinlerden biri olan kollajen, cildin yapısal bütünlüğü ve gerilme işlevinde önemli rol oynamaktadır $(20,21)$. Diyabetik ciltte, ileri glikasyonun son ürünleri olan AGE'lerin artışına neden olur. AGE'ler, glukoz veya aldehit moleküllerinin keton grubu ile proteinlerin amino grupları arasındaki enzimatik olmayan bir reaksiyon olan Maillard işlemi tarafından oluşturulur. Derinin dermis tabakasında kolaylıkla birikim yaparak fibroblast ve kollajen fonksiyonlarını doğrudan etkilemektedir. Nonenzimatik reaksiyonların ürettiği glikatlı kollajen diyabetin süresine bağlı olarak ta değişkenlik göstermektedir. Bu durum ve elde edilen bulgular ışığında diyabette kollajen organizasyonunda bozulma sonucu cildin yapısal bütünlüğünü ve mekanik özelliklerini bozulmakta ve normal deriye kıyasla diyabetik deride parçalanmış ve çapraz bağlanmış kolajen birikimi oluşmakta ve bunun bir sonucu olarak diyabetik cildin yaşlanmış cilde benzer görünmesine neden olabileceği görülmüştür $(2,22)$.

Propolis, bal arıları tarafından yapılan reçineli maddelerin yapışkan bir karışımı olarak bilinmekte ve içeriğinde $\% 50$ reçine, \%30 mum, \%10 uçucu ve aromatik yağlar, \%5 polen ve $\% 5$ diğer organik maddeler bulunduğu bildirilmektedir $(23,24)$. Günümüzde 300 'ün üzerinde kimyasal bileşeni tanımlanmış ve yapılan araştırmaların sonucunda, propolisin kimyasal bileşiminin coğrafi bölgeye ve arı türüne bağlı olarak farklılık gmsterebileceği belirtilmiştir (23). Propolisin biyolojik aktiviteleri incelendiğinde, antihiperglisemik, antioksidan, anti-inflamatuar, anti-apoptotik, anti-mikrobiyal, renoprotektif, kardiyoprotektif ve hepatoprotektif etkileri olduğu yapılan çalışmalarda vurgulanmaktadır $(23,25,26)$. Fakat yapılan klinik ve hayvan deneyleri çalışmaları arasında çelişkili sonuçlardan dolayı propolisin tamamlayıcı bir tedavi olarak kullanımının hala araştırmalar ile desteklenmeye ihtiyaç duyulmaktadır. Usman ve ark.'nın (2018) yaptığı bir çalışmada, propolisin diyabetin neden olduğu bozulmuş gebelik sonuçlarına 
karşı ve insülin tedavisine ek olarak uygulandığında plasental oksidatif strese karşı koruyucu etkileri olabileceği belirtilmiştir (27). Bazmandegan ve ark.'nın (2017) deneysel inme modelinde, İran'ın iki farklı bölgesinden toplanan propolisin $100 \mathrm{mg}$ ve $200 \mathrm{mg}$ dozlarının, serebral iskemiye bağlı oluşan oksidatif hasara karşı belirgin derecede iyileştirici etkisi olduğu vurgulanmıştır (28). Son yapılan çalışmalarda propolisin glukoz metabolizması, lipidler, insülin ve antioksidan aktiviteleri üzerindeki etkinliğini araştıran çalışmalarda, propoliste bulunan bileşiklerin insülini güçlendirici özelliklere sahip olduğunu ve oksidatif stres belirteçlerini iyileştirdiğini, diyabetin komplikasyonlarının azalttığı belirtilmiştir (29). Biz bu çalışmada propolisin pek çok yapılan çalışmada belirtilen sonuçlara ek olarak diyabetin neden olduğu dermal hasara karşı 100mg / kg propolis dozunun iyileştirici etkisini araştırdık. Elde edilen sonuçlara göre; DM+Propolis 100mg grubunda DM grubunda izlenen epitel tabakasındaki bozulmaların düzeldiği, epitel katmanlarında artış görülmeye başlandığı, papillar ve retiküler dermiste DM grubuna göre kollajen miktarında artış olduğu gözlendi.

Sonuç olarak, STZ ile meydana gelen diyabet modelinde 28. günde belirgin şekilde dermal hasarın olduğu, kollajen organizasyonunda bozulma sonucu cildin yapısal bütünlüğünü bozulmakta ve normal deriye kıyasla diyabetik cildin yaşlanmış cilde benzer görünmesine neden olabileceği görülmüştür. Bununla birlikte 28 gün boyunca $100 \mathrm{mg} / \mathrm{kg}$ Propolis ek takviyesinin bu izlenen bulguları morfolojik açıdan değerlendirildiğinde iyileştirmede destek olabileceği kanaatindeyiz.

Etik onam: Çalışma için Harran Üniversitesi Hayvan Deneyleri Yerel Etik Kurulu'ndan (Karar no: 2021/005/07) onay alındı.

\section{Yazar Katkıları:}

Konsept: S.T.

Literatür Tarama: S.T.

Tasarım: S.T.

Veri toplama: S.T.

Analiz ve yorum: S.T.

Makale yazımı: S.T.

Eleştirel incelenmesi: S.T.

Çıkar Çatışması: Herhangi bir çıkar çatışmamız bulunmamaktadir.

Finansal Destek: Araştırma kapsamında herhangi bir kurum ya da kuruluştan finansal destek sağlanmamıştır.

\section{Kaynaklar}

1- Su HC, Hung LM, Chen JK. Resveratrol, a red wine antioxidant, possesses an insulin-like effect in streptozotocin-induced diabetic rats. Am J Physiol Endocrinol Metab. 2006; 290(6):1339-46.

2- Tunali S, Yanardag R. Protective effect of vanadyl sulfate on skin injury in streptozotocin-induced diabetic rats. Hum Exp Toxicol. 2013, 32(11):1206-12.

3- Suh Y, Moon J, Yoon JY, Kim SW, Choi YS. Effects of Initiation Time of Glycemic Control on Skin Collagen Recovery in Streptozotocin-Induced Diabetic Rats. Dermatology. 2018,
234(3-4):148-56.

4- Tosi B, Donini A, Rmagnoli C, Bruni A. Antimicrobial Activity and Chemical Extracts of Propolis Prepared with Different Solvents. Phytotherapy Research. 1996, 10(4):335-36.

5- Scheller S, Wilczok T, Imielski S, Krol W, Gabrys J, Shani J. Free radical scavenging by ethanol extract of propolis. Int J Radiat Biol. 1990; 57(3): 461-65.

6- Rezzani R, Giugno L, Buffoli B, Bonomini F, Bianchi R. The protective effect of caffeic acid phenethyl ester against cyclosporine A induced cardiotoxicity in rats. Toxicology. 2005; 212(2-3):155-64.

7- Mollaoglu H, Gokcimen A, Ozguner F, Oktem F, Koyu A, Kocak A, Demirin H, Gokalp O, Cicek E. Caffeic acid phenethyl ester prevents cadmium-induced cardiac impairment in rat. Toxicology. 2006;227(1-2):15-20.

8- Okutan H, Ozcelik N, Yilmaz HR, Uz E. Effects of caffeic acid phenethyl ester on lipid peroxidation and antioxidant enzymes in diabetic rat heart. Clin Biochem. 2005;38(2):191-6.

9- Tohamy AA, Abdella EM, Ahmed RR, Ahmed YK. Assessment of anti-mutagenic, anti-histopathologic and antioxidant capacities of Egyptian bee pollen andpropolis extracts. Cytotechnology. 2014;66(2):283-97.

10- Akyol S, Ugurcu V, Altuntas A, Hasgul R, Cakmak O, Akyol $O$. Caffeic acid phenethyl ester as a protective agent against nephrotoxicity and/or oxidative kidney damage: adetailed systematic review. ScientificWorldJournal. 2014;2014 Jun 3. doi: 10.1155/2014/561971. [Epub ahead of print].

11- Murata K, Yatsunami K, Fukuda E, Onodera S, Mizukami O, Hoshino G, Kamei T. Antihyperglycemic effects of propolis mixed with mulberry leaf extract on patients with type 2 diabetes. Altern Ther Health Med. 2004;10(3):78-9.

12- Askari VR, Rahimi VB, Zamani P, Fereydouni N, RahmanianDevin P, Sahebkar AH, Rakhshandeh H. Evaluation of the effects of Iranian propolis on the severity of post operational-induced peritoneal adhesion in rats. Biomed Pharmacother. 2018;99:346-353.

13- Ates O, Cayli SR, Yucel N, Altinoz E, Kocak A, Durak MA, Turkoz $Y$, Yologlu S. Central nervous system protection by resveratrol in streptozotocin-induced diabetic rats. J Clin Neurosci. 2007;14(3):256-60.

14- Demirseren DD, Emre S, Akoglu G, Arpaci D, Arman A, Metin A, Çakır B. Relationship between skin diseases and extracutaneous complications of diabetes mellitus: clinical analysis of 750 patients. Am J Clin Dermatol. 2014;15: 6570.

15- Chen X, Lin W, Lu S, Xie T, Ge K, Shi Y, Zou J, Liu Z, Liao W. Mechanistic study of endogenous skin lesions in diabetic rats. Exp Dermatol. 2010;19(12):1088-95.

16- Greig A V, James S E, McGrouther D A, Terenghi G, Burnstock $G$. Purinergic receptor expression in the regeneration epidermis in a rat model of normal and delayed wound healing. Exp Dermatol. 2003;12: 860-71.

17- Wang C M, Lincoln J, Cook J E, Becker D L. Abnormal connexin expression underlies delayed wound healing in diabetic skin. Diabetes 2007;56: 2809-817.

18- Rajkumar L, Srinivasan N, Balasubramanian K, Govindarajulu P: Increased degradation of dermal collagen in diabetic rats. Indian J Exp Biol. 1991;29: 1081-083.

19- Argyropoulos AJ, Robichaud P, Balimunkwe RM, Fisher GJ, Hammerberg C,Yan Yan Y, Quan T. Alterations of Dermal Connective Tissue Collagen in Diabetes: Molecular Basis of 
Aged-Appearing Skin. PLoS One.2016 Apr 22;11(4):e0153806. doi: 10.1371/journal.pone.0153806.

20- Wess TJ. Collagen fibril form and function. Adv Protein Chem. 2005;70: 341-74.

21- Reiser KM. Nonenzymatic glycation of collagen in aging and diabetes. Proc Soc Exp Biol Med. 1998 218: 23-37.

22- Okano Y, Masaki H, Sakurai H: Dysfunction of dermal fibroblasts induced by advanced glycation end-products (AGEs) and the contribution of a nonspecific interaction with cell membrane and AGEs. J Dermatol Sci. 2002;29:171-80.

23- Nna VU, Bakar ABA, Ahmad A, Eleazu CO, Mohamed M. Oxidative Stress, NF-kB-Mediated Inflammation and Apoptosis in the Testes of Streptozotocin-Induced Diabetic Rats: Combined Protective Effects of Malaysian Propolis and Metformin. Antioxidants (Basel). 2019; 8(10):465.

24- Burdock GA. Review of the biological properties and toxicity of bee propolis (propolis). Food Chem. Toxicol. 1998;36(4):347-63.

25- Çilenk KT, Öztürk I, Sönmez MF. 2016. Ameliorative effect of propolis on the cadmium-induced reproductive toxicity in male albino rats. Exp Mol Pathol. 101:207-213.

26- Yuluğ $E$, Türedi $S$, Yıldırım Ö, Yenilmez E, Aliyazıcıoğlu Y, Demir S, Özer-Yaman S, Menteşe A. Biochemical and morphological evaluation of the effects of propolis on cisplatin induced kidney damage in rats. Biotech Histochem. 2019 ;94(3):204-13.

27- Usman UZ, Bakar ABAB, Mohamed M. Propolis improves pregnancy outcomes and placental oxidative stress status in streptozotocin-induced diabetic rats BMC Complement Altern Med. 2018 Dec 5;18(1):324. doi: 10.1186/s12906018-2391-6.

28- Bazmandegan G, Boroushaki MT, Shamsizadeh A, Ayoobi F, Hakimizadeh E, Allahtavakoli M. Brown Oxidative Medicine and Cellular Longevity propolis attenuates cerebral ischemia-induced oxidative damage via affecting antioxidant enzyme system in mice. Biomedicine \&Pharmacotherapy. 2017 Jan;85:503-510. doi: 10.1016/j.biopha.2016.11.057.

29- Afsharpour F, Javadi $M$, Hashemipour $S$, Koushan $Y$, Haghighian HK. Propolis supplementation improves glycemic and antioxidant status in patients with type 2 diabetes: A randomized, double-blind, placebo-controlled study. Complement Ther Med. 2019 Apr;43:283-288. doi: 10.1016/j.ctim.2019.03.001. 